\title{
Potential for chromium (VI) bioremediation by the aquatic carnivorous plant Utricularia gibba L. (Lentibulariaceae)
}

\author{
Joanna Augustynowicz • Krzysztof Lukowicz • \\ Krzysztof Tokarz • Bartosz Jan Plachno
}

Received: 25 October 2014 / Accepted: 19 January 2015 / Published online: 31 January 2015

(C) The Author(s) 2015. This article is published with open access at Springerlink.com

\begin{abstract}
The aquatic carnivorous plant Utricularia gibba has one of the smallest known genomes among flowering plants, and therefore, it is an excellent model organism for physiological and developmental studies. The main aim of our work was to check whether the ubiquitous $U$. gibba might be useful for the phytoremediation of the highly toxic and mobile hexavalent chromium in waters. Plants were incubated for 1 week in a $50 \mu \mathrm{M}\left(2.6 \mathrm{mg} \mathrm{dm}^{-3}\right) \mathrm{Cr}(\mathrm{VI})$ solution in laboratory conditions. Our results revealed that the plant exhibits a very high accumulation capacity for $\mathrm{Cr}$. The accumulation level was higher than $780 \mathrm{mg} \mathrm{kg}^{-1}$ and a bioconcentration factor $>300$. On the other hand, the plants showed a low tolerance to the elevated $\mathrm{Cr}$ concentration, which was expressed in a significant decrease of the photosystem II activity. However, the most pronounced negative influence of chromate was found on the morphology and activity of the traps. Due to its high accumulation capacity, we suggest that $U$. gibba may be efficient in the removal of chromate over a short time scale. It can also provide a new molecular resource for studying the mechanisms of $\mathrm{Cr}(\mathrm{VI})$ detoxification.
\end{abstract}

Responsible editor: Elena Maestri

J. Augustynowicz $\cdot$ K. Tokarz

Unit of Botany and Plant Physiology, Institute of Plant Biology and

Biotechnology, Faculty of Biotechnology and Horticulture,

University of Agriculture in Kraków, Al. 29 Listopada 54,

31-425 Kraków, Poland

K. Łukowicz

Faculty of Animal Science, University of Agriculture in Kraków, Al. Mickiewicza 24, 30-059 Kraków, Poland

B. J. Płachno $(\square)$

Department of Plant Cytology and Embryology, Jagiellonian University in Kraków, Gronostajowa 9 St., 30-387 Kraków, Poland

e-mail: bartosz.plachno@uj.edu.pl
Keywords Aquatic carnivorous plants $\cdot$ Chlorophyll fluorescence $\cdot$ Chromium $\cdot$ Heavy metals $\cdot$ Phytoremediation

\section{Introduction}

The Water Framework Directive (WFD) has been in force across the member countries of the European Union since 2000. The main objective of the WFD is to ensure the protection of water and suitable levels of water ecology and chemical purity. In cleaning up the environment, there is an alternative to the physicochemical methods in the form of biological methods. Phytoremediation particularly denotes the use of plants to remove pollutants from water, soil, and air and/or to transform these pollutants into less harmful forms. Plants are capable of absorbing metal pollutants and transferring them to their aboveground parts (phytoextraction) and - as is the case for some species - of accumulating them in large quantities (phytoaccumulation) (Ali et al. 2013).

Chromium occurs naturally in two stable oxidation forms, which are $\mathrm{Cr}(\mathrm{III})$ and $\mathrm{Cr}(\mathrm{VI})$. However, these two forms are principally different in their physicochemical properties and toxicities. In solutions, $\mathrm{Cr}(\mathrm{VI})$ occurs as a chromate or dichromate anion. It is an extremely strong oxidant that is highly soluble within a wide range of $\mathrm{pH}$ and thus is easily bioavailable (Kotaś and Stasicka 2000). It can act as an oxidizing agent itself, and it can also induce the formation of free radicals during its conversion to $\mathrm{Cr}(\mathrm{III})$. Hexavalent chromium has mutagenic and carcinogenic effects on humans and animals. It is also highly toxic to plants (Saha et al. 2011; Zayed and Terry 2003). $\mathrm{Cr}$ (III) is less toxic, and in low concentrations, it is a microelement in the diet of mammals (Schwartz and Mertz 1959). Chromium pollution (resulting mainly from metal industries and leather manufacturers) constitutes a significant issue 
not only in developed countries (e.g., the USA) but also in developing ones (e.g., India). Because of the concentrations of chromium in waters, which often exceed the permissible levels, both $\mathrm{Cr}(\mathrm{VI})$ and $\mathrm{Cr}(\mathrm{III})$ compounds are regarded as priority toxic pollutants (EPA Water Quality Standards) by the US Environmental Protection Agency (US EPA).

The phytoextraction/phytoaccumulation of metals in natural water ecosystems, which is based on the use of aquatic vascular plants (macrophytes), is a competitive strategy compared to other bioremediation methods. The benefits of using vascular plants include eliminating pollutants in in situ conditions, the easy collection of biological material, and the absence of risk to the migration of organisms in soil-aquatic environments. Several macrohydrophytes and wetland plants are used for the bioremediation of water that has been polluted by metallic compounds (e.g., Augustynowicz et al. 2010, 2014; Axtell et al. 2003; Deng et al. 2004; Malec et al. 2011; Ye et al. 1997a, b).

Utricularia gibba is a ubiquitous carnivorous plant. There are more than 800 species of carnivorous plants that trap, kill, and absorb nutrients from various organisms (Darnowski et al. 2006; Juniper et al. 1989; Król et al. 2012). Some of these (Sarracenia purpurea ssp. purpurea, Drosera rotundifolia, Pinguicula sp.) were recorded in environments with soil that was rich in heavy metals (D'Alessi 2004). There have also been observations of two species of bladderworts (Utricularia australis and Utricularia intermedia) in aquatic environments in Poland that had been heavily polluted by $\mathrm{Tl}$ as well as by other heavy metals $(\mathrm{Cd}, \mathrm{Pb}$, and $\mathrm{Zn})$ (Płachno and Augustynowicz unp.). Why did we choose U. gibba? This species, which was recently sequenced and analyzed (IbarraLaclette et al. 2011 and 2013), like Genlisea margaretae (63 Mb, Greilhuber et al. 2006) and Genlisea aurea (63.6 Mb, Leushkin et al. 2013), has one of the smallest known genomes in flowering plants $(82-\mathrm{Mb}$ genome- approximately half that of Arabidopsis). Thus, U. gibba is an excellent model organism for physiological and developmental studies; some of these have begun (e.g., Chormanski and Richards 2012; Juang et al. 2011). Moreover, it has a broad geographic range (all continents except for Antarctica and it was introduced into Europe) and plasticity in the case of its habitats (Taylor 1989). U. gibba is also small in size, and it is easy to cultivate (D'Amato 1998; Schnell 2002).

The main aims of our study were:

- to determine the ability of $U$. gibba to accumulate and tolerate heavy metals in its tissues,

- to assess the potential use of $U$. gibba in phytoremediation.

In order to implement the objectives, we tested the accumulation capacity of the species for $\mathrm{Cr}$. The biochemical aspects of $\mathrm{Cr}(\mathrm{VI})$ 's influence on plant metabolism like the activity of photosystem II (PSII) as well as chlorophyll $a$, chlorophyll $b$, and carotenoid content were analyzed. We also performed a detailed analysis of the activity and morphology of the traps that were under the influence of $\mathrm{Cr}(\mathrm{VI})$.

\section{Material and methods}

Plant material and accumulation tests

Plants of $U$. gibba L. (subgenus Utricularia, section Utricularia) were obtained from the Botanical Garden of Jagiellonian University in Kraków, Poland, and later cultured in the Institute of Plant Biology and Biotechnology at the University of Agriculture in Kraków. The light conditions of the plant cultures and the composition of the medium were chosen based on the results of 2-month preliminary tests. Before starting the experiments with $\mathrm{Cr}$, the shoots were rinsed several times with distilled water after tap water. A Cr solution was prepared using twice-diluted macroelements and microelements of a standard MS medium, $\mathrm{pH} 5.4$, supplemented with $50 \mu \mathrm{M}\left(2.6 \mathrm{mg} \mathrm{dm}^{-3}\right) \mathrm{Cr}(\mathrm{VI})\left(\right.$ as $\mathrm{K}_{2} \mathrm{CrO}_{4}$; POCh Gliwice, Poland). This $\mathrm{Cr}$ concentration was selected based on the results of earlier experiments of the authors (Augustynowicz et al. 2010). Two grams of plant biomass were incubated in $200 \mathrm{~cm}^{-3}$ solutions. Incubations were conducted for 7 days under controlled conditions: 16-h photon flux density ca. $40 \mu \mathrm{mol} \mathrm{m} \mathrm{m}^{-2} \mathrm{~s}^{-1}$ and 8-h darkness, $23-24{ }^{\circ} \mathrm{C}$. The control samples were plants that were incubated as described above but with no Cr added.

\section{$\mathrm{Cr}$ content analysis}

Before the analysis of $\mathrm{Cr}$ content in the shoots, the plant material was thoroughly washed three times with distilled water and then dried for $24 \mathrm{~h}$ at $105^{\circ} \mathrm{C}$. Digestion was performed in a mixture of $\mathrm{H}_{2} \mathrm{O}_{2}$ and $\mathrm{HNO}_{3}(6: 1 ; v / v)$ (Suprapur, Merck) in a closed system of a microwave oven (Multiwave 3000, AntonPaar). Inductively coupled plasma mass spectrometry (ICP-MS) (ELAN 6100, Perkin Elmer) was used to measure the amount of $\mathrm{Cr}$ in the samples. The spectrometer was calibrated using the ICP multielement standard (Merck).

Measurements of physiological status of plants

Hydration of Utricularia shoots was measured after drying the plants at $105{ }^{\circ} \mathrm{C}$ for $24 \mathrm{~h}$. Photosynthetic pigments, chlorophylls $a$ and $b$, and carotenoids were isolated using the method described by Świderski (1998) in which $0.1 \mathrm{~g}$ of the shoots was homogenized in acetone (POCh Gliwice, Poland) with a small amount of $\mathrm{CaCO}_{3}$ (POCH Gliwice, Poland) in order to neutralize the organic acids, after which they were centrifuged for $15 \mathrm{~min}, 5400 \mathrm{~g}$, at $4{ }^{\circ} \mathrm{C}$ (Rotina 380 -R, Hettich Zentrifugen, Germany). The pigment content was calculated in accordance with the equations presented by Lichtenthaler 
and Wellburn (1983) after the measurements of absorbance (UV-Vis spectrophotometer, HITACHI U-2900) at 470, 645, and $662 \mathrm{~nm}$.

The chlorophyll fluorescence was determined using a chlorophyll fluorescence monitoring system (FluorCam, Photon Systems Instruments, Czech Republic) according to the standard procedure as modified for water plants as described by Augustynowicz et al. (2014). The PSII maximal photochemical quantum yield $\left(\mathrm{F}_{\mathrm{V}} / \mathrm{F}_{\mathrm{M}}\right)$, which was calculated as $\left(\mathrm{F}_{\mathrm{M}}-\right.$ $\mathrm{F}_{0}$ ) $/ \mathrm{F}_{\mathrm{M}}$, was obtained after dark adaptation for at least $20 \mathrm{~min}$, which is necessary for the measurement of the basic chlorophyll fluorescence yield $\left(F_{0}\right)$. The maximal chlorophyll fluorescence yield $\left(\mathrm{F}_{\mathrm{M}}\right)$ was recorded by applying a 0.8 -s saturating light pulse $\left(2000 \mu \mathrm{mol} \mathrm{m}^{-2} \mathrm{~s}^{-1}\right)$.

An original Paramecium test was developed in order to detect the activity of the traps that were under the influence of Cr. Paramecia were house-stock cultured in $500 \mathrm{ml}$ glass containers at room temperature and stored out of direct sunlight for 7 days. The house-stock was prepared using dechlorinated tap water containing 3-5 g of hay and banana peel. The composition of the hay was as follows: Plantago maior, Plantago lanceolata, Taraxacum officinale, Urtica dioica, and Achillea millefolium. It was commercially available hay for small rodents. The culture was regularly aerated. Before application, the vitality and number of Paramecium cells were analyzed. In order to measure the activity of the traps, $1 \mathrm{~cm}^{-3}$ of the described Paramecium stock was incubated with $0.5 \mathrm{~g}$ of Utricularia in a $25 \mathrm{~cm}^{-3}$ culture medium (Cr-containing or control) for $48 \mathrm{~h}$. After the incubation, shoots of Utricularia were exhaustively washed with a halfstrength MS medium to detach any protozoa cells that may have remained on the surface. The activity of the traps was expressed as the number of Paramecium that had been absorbed by the traps. It was computed as the difference between the number of Paramecium in the incubation medium at the start and at the end of the incubation. The quantity of Paramecia was calculated under an optical microscope (Opta-Tech, Poland) using a Bürker chamber. For that reason, the protozoa were treated for $2 \mathrm{~min}$ at $-20{ }^{\circ} \mathrm{C}$ in order to immobilize them. The total volume of solutions used and the fresh weight of shoots were always taken into account in the calculations. The negative effect of $\mathrm{Cr}(\mathrm{VI})$ on Paramecium vitality was also tested. No influence of $\mathrm{Cr}(\mathrm{VI})$ on the number or mobility of Paramecium was found under the conditions of the described test.

Microscopy analysis

\section{Light microscopy}

Fresh plant material was examined using an Olympus BX60 fluorescence/light microscope.

\section{Scanning electron microscopy}

Material was fixed in $5 \%$ glutaraldehyde in a phosphate buff$\mathrm{er}(\mathrm{pH}$ 7.4). The samples were dehydrated in serial dilutions of ethanol and acetone, after which they were critical point dried in liquid $\mathrm{CO}_{2}$ and coated with gold using a JEOL-JFC 1100E sputter coater. The specimens were viewed under a HITACHI S-4700 microscope (Scanning Microscopy Laboratory of Biological and Geological Sciences, Jagiellonian University in Kraków) at $20 \mathrm{kV}$.

\section{Statistics}

The Student's $t$ test or Mann-Whitney $U$ test (if data were not normally distributed) were used to compare any significant differences in pairs (control and Cr-treated samples) at $\alpha=$ 0.05 based on STATISTICA ver. 10 software (StatSoft Inc. 2011). Up to four sets of independent experiments with several independent replicates in each set were performed.

\section{Results}

Cr accumulation tests revealed that after a 7-day incubation in a chromate solution, the shoots of Utricularia were able to accumulate an average of $787.4 \mathrm{mg} \mathrm{kg}^{-1}( \pm 179.6)(n=4)$. $\mathrm{Cr}$ in the control plants was detected at an average level of $3.3 \mathrm{mg} \mathrm{kg}^{-1}( \pm 2.1)(n=4)$. The bioconcentration factor (BCF), which is defined as the ratio of Cr quantity in tissue ( $\mathrm{mg} \mathrm{kg}^{-1}$ d.w.) to the $\mathrm{Cr}$ quantity in solution $\left(\mathrm{mg} \mathrm{kg}^{-1}\right)$, was slightly above 300 .

Regarding the physiological status of shoots, we did not observe any differences in the tissue hydration between the Cr-influenced and control plants. The dried mass accounted for $7.82 \%( \pm 0.75)$ or $7.74 \%( \pm 1.34)$ in the case of the $\mathrm{Cr}$ influenced and control plants, respectively $(p>0.05 ; n=7)$. There were also no differences in the general morphology of the shoots between the control and $\mathrm{Cr}(\mathrm{VI})$-exposed plants. On the other hand, a decrease in the content of photosynthetic pigments was detected, although $\mathrm{Cr}(\mathrm{VI})$ did not severely affect the concentration of photosynthetic pigments after the 7day incubation. Significant statistical differences between the control and Cr-exposed plants were observed only for chlorophyll $a$. The level of chlorophyll $b$ and carotenoids were lower in the stressed plants but not significantly (Fig. 1). The impact of hexavalent chromium on a plant's photosynthetic apparatus was also measured based on the analysis of chlorophyll $a$ fluorescence. It was manifested by a statistically significant decrease in the PSII maximal photochemical quantum yield $\left(\mathrm{F}_{\mathrm{V}} / \mathrm{F}_{\mathrm{M}}\right)$. The spatial distribution of the $\mathrm{F}_{\mathrm{V}} / \mathrm{F}_{\mathrm{M}}$ parameter in Utricularia shoots is presented in Fig. 2. The lower PSII efficiency was related to a statistically significant increase in the basic chlorophyll fluorescence yield $\left(\mathrm{F}_{0}\right)$ in the bladderwort 


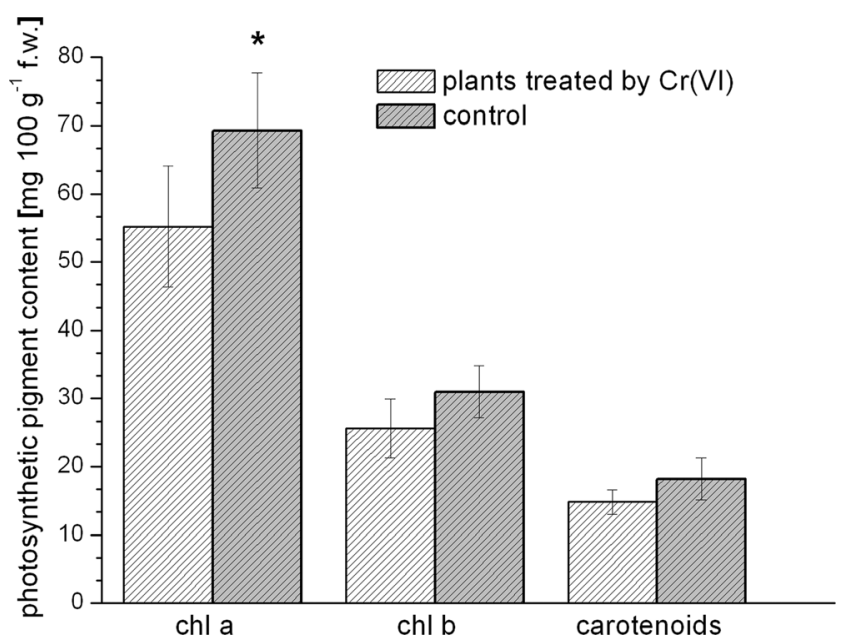

Fig. 1 The content ( $\mathrm{mg} \mathrm{g}^{-1}$ fresh weight) of chlorophyll $a$, chlorophyll $b$, and carotenoids in the control as well as in the $\mathrm{Cr}(\mathrm{VI})$-treated plants. Statistically significant differences in pairs were found for chl $a$, which are marked with an asterisk (Student's $t$ test at $\alpha=0.05$; chl a $p<0.023$; chl $b p<0.065$; carotenoids $p<0.074)$. Error bars represent SDs; $n=6$

shoots that had been incubated in the chromate solution, which is in accordance with the decrease in chlorophyll $a$. In contrast, the variable fluorescence $\left(\mathrm{F}_{\mathrm{V}}\right)$ stayed at a level that was similar to the control plants (Table 1).

The results that were obtained showed pronounced changes in the activity as well as in the morphology of the traps that had been subjected to $\mathrm{Cr}(\mathrm{VI})$. The average number of Paramecia that were absorbed by the $\mathrm{Cr}(\mathrm{VI})$-treated traps was approximately three times lower than in the case of the control samples (Table 2). Although the activity of the traps was disturbed, the number of traps on shoots did not change under the influence of chromate even after the prolonged time of the experiment (data not shown). The altered activity of the traps, however, correlated with the morphological distortion of traps. In comparison to the control (Fig. 3a, b), the new traps of the plants that had been subjected to $\mathrm{Cr}(\mathrm{VI})$ were inhibited in development and were not functional (Fig. 3c, d). These immature traps did not have a functional trap door

\section{Control}

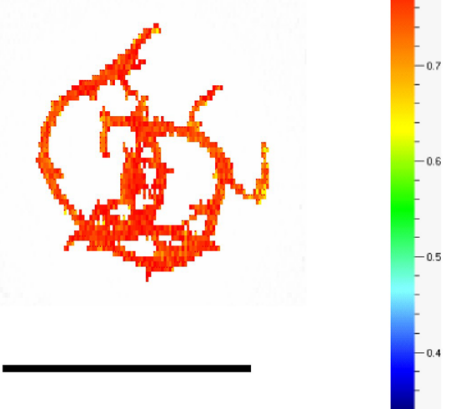

Fig. 2 Representative spatial distribution of the fluorescence emission of bladderwort shoots. The color scale represents the PSII maximal photochemical quantum yield $\left(\mathrm{F}_{\mathrm{V}} / \mathrm{F}_{\mathrm{M}}\right)$. Bar $=30 \mathrm{~mm}$
Table $1 \mathrm{Cr}(\mathrm{VI})$ impact on selected fluorescence parameters of bladderworts shoots

\begin{tabular}{lccl}
\hline & Control & Cr-influenced & Significance \\
\hline $\mathrm{F}_{0}$ & $80.0 \pm 19.0$ & $135.7 \pm 16.5$ & $*$ \\
$\mathrm{~F}_{\mathrm{V}}$ & $319.3 \pm 88.2$ & $336.8 \pm 28.2$ & $\mathrm{~ns}$ \\
$\mathrm{~F}_{\mathrm{V}} / \mathrm{F}_{\mathrm{M}}$ & $0.7 \pm 0.0$ & $0.6 \pm 0.1$ & $*$ \\
\hline
\end{tabular}

Asterisk indicates significant difference (Student $t$ test at $\alpha=0.05 ; \mathrm{F}_{0}$ $p<0.009 ; \mathrm{F}_{\mathrm{V}} p<0.300 ; \mathrm{F}_{\mathrm{V}} / \mathrm{F}_{\mathrm{M}} p<0.001$

with trigger hairs, and therefore, they could not catch Paramecia (Fig. 3d). Plants also produced these nonfunctional traps after the prolonged time of the experiment (data not shown).

\section{Discussion}

The average chromium content in surface waters is usually at a low level, typically between a few fractions of microgram to a few micrograms per cubic decimeter (Kabata-Pendias and Mukherjee 2007). The quantity of $\mathrm{Cr}(\mathrm{VI})$ in surface waters that is acceptable by the US EPA (EPA Water Quality Standards) is $15 \mu \mathrm{g} \mathrm{dm}^{-3}$. With respect to this level, the concentration used in our experiment $\left(50 \mu \mathrm{M}=2.6 \mathrm{mg} \mathrm{dm}^{-3}\right)$ was more than 170 times higher and corresponded to the $\mathrm{Cr}$ amount in a polluted river environment (e.g., Liu et al. 2013). U. gibba was able to effectively accumulate this toxic element in such heavily $\mathrm{Cr}(\mathrm{VI})$-polluted water. However, it must be stressed that a comparison between different plant species, which is related to the phytoextraction potential of a particular element, is sometimes difficult to perform. This is due to the fact that it depends on a number of factors: the time of the incubation, the concentration of metallic compound, the chemical form of the metal that is used, $\mathrm{pH}$, the redox potential of the medium etc. Nevertheless, we showed that the accumulation level of $\mathrm{Cr}$ by $U$. gibba was more than a magnitude higher when compared to other free-floating macrophytes such as Pistia stratiotes, Spirodela polyrhiza, and Eichhornia crassipes (Mishra and Tripathi 2008), which grow in similar $\mathrm{Cr}(\mathrm{VI})$-containing hydroponic cultures. These

Table 2 Activity of traps expressed as a number of Paramecium adsorbed by traps (of $1 \mathrm{~g}$ f.w.) during 48-h incubation of Utricularia plants in $\mathrm{Cr}(\mathrm{VI})$-containing and control medium

\begin{tabular}{lllll}
\hline & Mean & SD & Min & Max \\
\hline Control & $2.93 \times 10^{7}$ & $0.85 \times 10^{7}$ & $2.16 \times 10^{7}$ & $4.10 \times 10^{7}$ \\
Cr-influenced & $1.07 \times 10^{7}$ & $0.82 \times 10^{7}$ & $0.29 \times 10^{7}$ & $2.12 \times 10^{7}$ \\
\hline
\end{tabular}

Significant differences were found between groups according to nonparametric Mann-Whitney $U$ test $(\alpha=0.05 ; p<0.030)$. Two sets of independent experiments with two independent replicates in each set and 20 independent counts in each replicate were performed 
Fig. 3 Morphology of traps of Utricularia gibba. a, b Traps of the control plants, bars $=500$ and $200 \mu \mathrm{m}$. c, d Traps of the Cr(VI)treated plants, bars $=500$ and $100 \mu \mathrm{m} . T$ trap, $A$ antennae; reduced antennae (arrow)
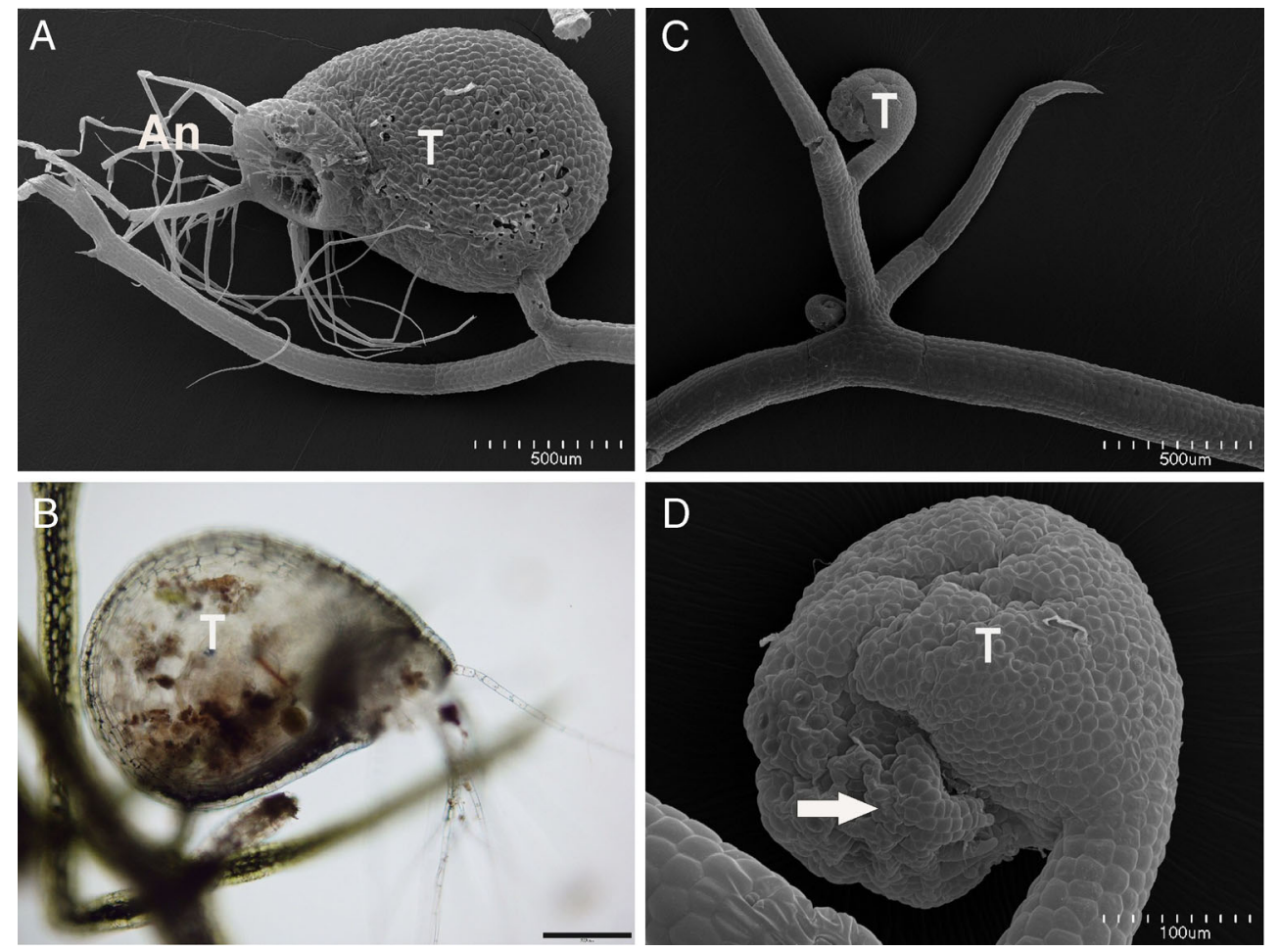

plants, especially E. crassipess, are known to be extraordinary phytoremediators of heavy metallic compounds in aquatic systems (Chandra and Kulshreshtha 2004; Zayed and Terry 2003; Sundaramoorthy et al. 2010). The abovementioned macrophytes when growing in a $\mathrm{Cr}(\mathrm{VI})$ concentration analogous to the one used in our experiment accumulated $306<98<$ 71 ( $\mathrm{mg} \mathrm{kg}^{-1}$ d.w.) for E. crassipes $<$ P. startiotes $<$ S. polyrhiza, respectively (Mishra and Tripathi 2008). In another work, Giri and Patel (2011) showed that E. crassipes that had been grown in a hydroponic culture that was supplemented with $2.5 \mathrm{mg} \mathrm{dm}^{-3}$ of $\mathrm{Cr}(\mathrm{VI})$ for 6 days was able to accumulate ca. $800 \mathrm{mg} \mathrm{kg}^{-1}$ d.w. of chromium, which is a value similar to that of the $U$. gibba that is presented in our work. Moreover, the accumulation of $\mathrm{Cr}$ by bladderwort was comparable to that of an outstanding $\mathrm{Cr}$ phytoremediator - a submersed Callitriche cophocarpa that had been cultured in $50 \mu \mathrm{M} \mathrm{Cr}(\mathrm{VI})$ under similar laboratory conditions (Augustynowicz et al. 2010). We also showed that U. gibba exhibited a high $\mathrm{BCF}=300$.

In our opinion, the uptake of $\mathrm{Cr}$ is performed by the whole plant surface. However, it should be emphasized that the ratio of the weight of the traps and the shoots is very low. Therefore, we believe that the plant's shoots are mainly responsible for the high $\mathrm{Cr}$ accumulation. Moreover, based on the results that are related to the $\mathrm{Cr}$ uptake, we would conclude that bladderwort can be considered to be a species that has a possible application for $\mathrm{Cr}(\mathrm{VI})$ phytoextraction purposes in aquatic systems. Unfortunately, an estimate of the accumulation of an element and its $\mathrm{BCF}$ is not enough to determine the application of a particular plant species in the cleanup of a polluted environment. The ideal plant for the practical use in phytoremediation, aside from exhibiting a considerable capacity for the metal uptake/degradation of xenobiotic, must also show i.a. a high tolerance for pollution. $U$. gibba was not found to be a plant that is highly resistant to $\mathrm{Cr}(\mathrm{VI})$. The $50 \mu \mathrm{M} \mathrm{Cr}(\mathrm{VI})$ that was used in our experiment induced a decrease in the photosynthetic pigment content in bladderwort tissues when compared to the control. Although the presence of chromate in the solution did not significantly alter the content of chlorophyll $b$ and carotenoids, a statistically significant decrease in the quantity of chlorophyll $a$ and fluorescence was observed. Our findings are in line with the literature data since a decrease in the photosynthetic pigment content is known to be the most sensitive response of plants to an increased heavy metal background (Appenroth 2010). C. cophocarpa that had been grown in the same $\mathrm{Cr}(\mathrm{VI})$ concentration for 5 days also showed some decrease in the pigment content, although the chlorophyll $a$ fluorescence was not altered by $\mathrm{Cr}(\mathrm{VI})$ under these conditions (Augustynowicz et al. 2010). On the other hand, floating $P$. stratiotes that had been exposed to $\mathrm{Cr}$-rich wastewater (35 and $50 \mathrm{mg} \mathrm{dm}^{-3}$ ) showed almost no influence of $\mathrm{Cr}$ on the chlorophyll content (Ganesh et al. 2008). The authors, however, did not distinguish the oxidation form of chromium that was used. The impact of $\mathrm{Cr}$ on living organisms depends very strongly on the form that is used. Hexavalent $\mathrm{Cr}$ compounds have been estimated to be one or even two magnitudes more toxic than trivalent compounds (Zayed and Terry 2003). U. gibba is a floating rootless plant, 
and therefore, its tolerance to pollution may also be lower than floating but rooted macrophytes like E. crassipess or $P$. stratiotes. These species accumulate most of the load of heavy metals in their root systems (Ganesh et al. 2008; Giri and Patel 2011), thus limiting the transfer of pollution to their mesophyll photosynthesizing tissues.

The impact of $\mathrm{Cr}$ on the photosynthetic apparatus may be related to either the donor or acceptor side of PSII reaction center (RC), PSI, as well as chloroplast ultrastructure disorganization (Shanker et al. 2005). In the case of $U$. gibba, the impact of $\mathrm{Cr}$, which was manifested by a decrease in the chlorophyll $a$ content as well as a high value of the basic chlorophyll fluorescence yield $\left(\mathrm{F}_{0}\right)$, might have resulted from the ultrastructure of the degradation of the chloroplasts. It was previously reported that the degradation of the chlorophyll membrane leads to a decrease in the energy transfer rate from the light-harvesting chlorophyll (chl) $a / b$ protein complexes to PSII (Domínguez et al. 2011). In addition, $\mathrm{Cr}$ is possibly responsible for the reduced size of the peripheral part of the antenna complex and may inactivate the activity of the enzymes that are involved in chlorophyll biosynthesis (Shanker et al. 2005). A high value of the basic chlorophyll fluorescence yield $\left(\mathrm{F}_{0}\right)$ and a lower value of the maximal chlorophyll fluorescence $\left(\mathrm{F}_{\mathrm{V}} / \mathrm{F}_{\mathrm{M}}\right)$ might reflect a permanent oxidation state of PSII reaction centers (Domínguez et al. 2011). Such changes might be caused by the oxidative activity of $\mathrm{Cr}$, which additionally may be responsible for damage to the RC of PSII, which is in line with the observations of other authors (Shanker et al. 2005; Stefanov et al. 1995; Domínguez et al. 2011).

Despite the decrease of $\operatorname{chl} a$ content and the activity of PSII, the whole plant was able to carry out photosynthesis in the presence of $\mathrm{Cr}(\mathrm{VI})$. Furthermore, the hydration of the plant did not change despite the fact that changes in the water balance (in addition to changes in the content of chlorophylls) are considered to be the first symptoms of the negative impact of heavy metals on plants (Appenroth 2010). However, the most pronounced negative influence of $\mathrm{Cr}(\mathrm{VI})$ was on the morphology and activity of the traps. Aquatic rootless carnivorous Utricularia usually grow in nutrient-poor waters and because of this prey is an important source of nutrients (mainly nitrogen and phosphorous) to these plants. It was found that prey capture in aquatic Utricularia leads to more rapid growth (Adamec 1997; Adamec 2008). Aquatic Utricularia traps are inhabited by various commensals (e.g., Sirová et al. 2009, 2010; Płachno et al. 2012). The host plant even grows bacteria and ciliates. Utricularia supplies available organic C to the microbial community that thrives within the trap environment while benefiting from its by-products/nutrients (Sirová et al. 2010). Chromate severely influenced the activity and morphology of the traps. Thus, the plants lost an additional source of nitrogen and phosphorus from both the carnivory and commensal communities that thrive within the trap, which may cause a loss of competitiveness of Utricularia in comparison with other macrophytes.

\section{Conclusions}

In our work, we proved that $U$. gibba can effectively extract $\mathrm{Cr}$ when it grows in water that has been polluted by the highly toxic $\mathrm{Cr}(\mathrm{VI})$ form. This element, however, negatively influenced the photosynthesis of the plant that was investigated, and it also influenced the activity and morphology of the traps far more severely. Nevertheless, due to its high $\mathrm{Cr}(\mathrm{VI})$ accumulation capacity, we suggest that $U$. gibba may be efficient in the removal of chromate over a short time scale, even if the plant's metabolism is altered. U. gibba may be an especially good species for chrome removal in oligotrophic environments that have low water $\mathrm{pH}$ and poor macrophyte flora.

Acknowledgments The work was financed by Grant No. DEC-011/03/ B/NZ9/00952 from the National Science Centre, Poland. B. J. Płachno gratefully acknowledges the scholarship awarded to Outstanding Young Scientists by the Minister of Science and Higher Education, Poland.

Open Access This article is distributed under the terms of the Creative Commons Attribution License which permits any use, distribution, and reproduction in any medium, provided the original author(s) and the source are credited.

\section{References}

Adamec L (1997) Mineral nutrition of carnivorous plants: a review. Bot Rev 63:273-299

Adamec L (2008) Mineral nutrient relations in the aquatic carnivorous plant Utricularia australis and its investment in carnivory. Fundam Appl Limnol 171:175-183

Ali H, Khan E, Sajad MA (2013) Phytoremediation of heavy metalsconcepts and applications. Chemosphere 91:869-881

Appenroth K-J (2010) What are "heavy metals" in plant sciences? Acta Physiol Plant 32:615-619

Augustynowicz J, Grosicki M, Hanus-Fajerska E, Lekka M, Waloszek A, Kołoczek H (2010) Chromium (VI) bioremediation by aquatic macrophyte Callitriche cophocarpa Sendtn. Chemosphere 79:10771083

Augustynowicz J, Tokarz K, Baran A, Płachno BJ (2014) Phytoremediation of water polluted by $\mathrm{Tl}, \mathrm{Cd}, \mathrm{Zn}$ and $\mathrm{Pb}$ with the use of macrophyte Callitriche cophocarpa. Arch Environ Contam Toxicol 66:572-581

Axtell N, Sternberg S, Claussen K (2003) Lead and nickel removal using Microspora and Lemna minor. Bioresour Technol 89:41-48

Chandra P, Kulshreshtha K (2004) Chromium accumulation and toxicity in aquatic plants. Bot Rev 70:313-327

Chormanski TA, Richards JH (2012) An architectural model for the bladderwort Utricularia gibba (Lentibulariaceae). J Torrey Bot Soc 139: $137-148$

D'Alessi F (2004) Report of a high latitude population of Sarracenia purpurea ssp purpurea growing on poisonous deep mantle rocks. In 5th I C P S Congress, Lyon, 2004. Ed. IC P Society. pp 33

D'Amato P (1998) The Savage Garden: cultivating carnivorous plants. Ten Speed Press, Berkeley, p 231, ISBN 0-89815-915-6 
Darnowski DW, Carroll DM, Płachno B, Kabanoff E, Cinnamon E (2006) Evidence of protocarnivory in triggerplants (Stylidium spp.; Stylidiaceae). Plant Biol 8:805-812

Deng H, Ye ZH, Wong MH (2004) Accumulation of lead, zinc, copper and cadmium by 12 wetland plants species thriving in metal contaminated sites in China. Environ Pollut 132(1):29-40

Domínguez MT, Marańón T, Murillo JM, Redondo-Gómez S (2011) Response of Holm oak (Quercus ilex subsp. ballota) and mastic shrub (Pistacia lentiscus L.) seedlings to high concentrations of $\mathrm{Cd}$ and $\mathrm{Tl}$ in the rhizosphere. Chemosphere 83:1166-1174

EPA Water Quality Standards, Section 304(a) criteria for priority toxic pollutants. http://www.ecfr.gov/cgi-bin/text-idx?c=ecfr\&SID= $0 \mathrm{~d} 9 \mathrm{ad} 6456 \mathrm{ca} 41 \mathrm{c} 8 \mathrm{adb} 0 \mathrm{~d} 2377 \mathrm{dd} 28 \mathrm{f} 853 \& \mathrm{rgn}=\mathrm{div} 5 \& \mathrm{view}=$ text\&node $=40: 23 \cdot 0 \cdot 1.1 .18 \& \mathrm{idno}=40 \# 40: 23 \cdot 0.1 .1 .18 .3 .16 .1$. Accessed 26 June 2014

Ganesh KS, Baskaran L, Rajasekaran S, Sumathi K, Chidambaram ALA, Sundaramoorthy (2008) Chromium stress induced alterations in biochemical and enzyme metabolism in aquatic and terrestrial plant $\mathrm{s}$. Colloids Surf 63:159-163

Giri AK, Patel RK (2011) Toxicity and bioaccumulation potential of $\mathrm{Cr}(\mathrm{VI})$ and $\mathrm{Hg}(\mathrm{II})$ on different concentration by Eichhornia crassipes in hydroponic culture. Water Sci Technol 63:899-907

Greilhuber J, Borsch T, Mueller K, Worberg A, Porembski S, Barthlott W (2006) Smallest angiosperm genomes found in Lentibulariaceae, with chromosomes of bacterial size. Plant Biol 8:770-777

Ibarra-Laclette E, Albert VA, Pérez-Torres CA, Zamudio-Hernández F, Ortega-Estrada Mde J, Herrera-Estrella A, Herrera-Estrella L (2011) Transcriptomics and molecular evolutionary rate analysis of the bladderwort (Utricularia), a carnivorous plant with a minimal genome. BMC Plant Biol 101. doi:10.1186/1471-2229-11-101

Ibarra-Laclette E et al (2013) Architecture and evolution of a minute plant genome. Nature 498/ 7452:94

Juang TC-C, Juang SD-C, Liu Z-H (2011) Direct evidence of the symplastic pathway in the trap of the bladderwort Utricularia gibba L. Bot Stud 42: 47-54

Juniper BE, Robins RJ, Joel DM (1989) The carnivorous plants. Academic, London

Kabata-Pendias A, Mukherjee AB (2007) Trace elements from soil to human. Springer Berlin Heidelberg New York

Kotaś J, Stasicka Z (2000) Chromium occurrence in the environment and methods of its speciation. Environ Pollut 107:263-283

Król E, Płachno BJ, Adamec L, Stolarz M, Dziubińska H, Trębacz K (2012) Quite a few reasons for calling carnivores the most wonderful plants in the world. Ann Bot 109:47-64

Leushkin EV, Sutormin RA, Nabieva ER, Penin AA, Kondrashov AS, Logacheva MD (2013) The miniature genome of a carnivorous plant Genlisea aurea contains a low number of genes and short noncoding sequences. BMC Genomics 14:476. doi:10.1186/14712164-14-476

Lichtenthaler HK, Wellburn AR (1983) Determination of total carotenoids and chlorophyll $a$ and $b$ of leaf extracts in different solvents. Biochem Soc 603:591-592
Liu Y-Q, Liu Y-G, Hu X-J, Guo Y-M (2013) Adsorption of $\mathrm{Cr}(\mathrm{VI})$ by modified chitosan from heavy-metal polluted water of Xiangjiang River, China. Trans Nonferrous Metals Soc China 23:3095-3103

Malec P, Myśliwa-Kurdziel B, Prasad MNV, Waloszek A, Strzałka K (2011) Role of aquatic macrophytes in biogeochemical cycling of heavy metals, relevance to soil-sediment continuum detoxification and ecosystem health. In: Sherameti I, Varma A (eds) Detoxification of heavy metals. Springer, Berlin, pp 345-368

Mishra VK, Tripathi BD (2008) Concurrent removal and accumulation of heavy metals by the three aquatic macrophytes. Biores Technol 99: 7091-7097

Płachno BJ, Łukaszek M, Wołowski K, Adamec L, Stolarczyk P (2012) Aging of Utricularia traps and variability of microorganisms associated with that microhabitat. Aquat Bot 97:44-48

Saha R, Nandi R, Saha B (2011) Sources and toxicity of hexavalent chromium. Review. J Coord Chem 64:1782-1806

Schnell D (2002) Carnivorous Plants of the United States and Canada. Timber Press, Portland, Oregon, pp 369-370, ISBN 0-88192-540-3

Schwartz K, Mertz W (1959) Chroimium (III) and the glucose tolerant factor. Arch Biochem Biophys 85:292-295

Shanker AK, Cervantes C, Loza-Tavera H, Avudainayagam S (2005) Chromium toxicity in plants. Environ Int 31:739-753

Sirová D, Borovec J, Cerná B, Rejmánková E, Adamec L, Vrba J (2009) Microbial community development in the traps of aquatic Utricularia species. Aquat Bot 90:129-136

Sirová D, Borovec J, Šantrucková H, Šantrucek J, Vrba J, Adamec L (2010) Utricularia carnivory revisited: plants supply photosynthetic carbon to traps. J Exp Bot 61:99-103

StatSoft, Inc. (2011) STATISTICA (data analysis software system), version 10. www.statsoft.com

Stefanov K, Seizova K, Popova I, Petkov V, Georgi K, Popov S (1995) Effect of lead ions on the phospholipid composition in leaves of Zea mays and Phaseolus vulgaris. J Plant Physiol 147:243-246

Sundaramoorthy P, Chidambaram A, Ganesh KS, UnnikannanpP, Baskaran L (2010) Chromium stress in paddy: (i) nutrient status of paddy under chromium stress; (ii) phytoremediation of chromium by aquatic and terrestrial weeds. CR Biol 333:597-607

Świderski A (1998) Analysis of pigments in plant material with traditional and modified methods. PhD Dissertation, University of Agriculture in Kraków (in Polish)

Taylor P (1989) The genus Utricularia - a taxonomic monograph. Kew B 14:1-735

Ye ZH, Baker AJM, Wong MH, Willis AJ (1997a) Copper and nickel uptake, accumulation and tolerance in populations of Typha latifolia L. New Phytol 136:469-480

Ye ZH, Baker AJM, Wong MH, Willis AJ (1997b) Zinc, Lead and cadmium tolerance, uptake and accumulation by the common reed, Phragmites australis (Cav.) Trin. Ex Steudel. Ann Bot 80:363-370

Zayed AM, Terry N (2003) Chromium in the environment: factors affecting biological remediation. Plant Soil 249:139-156 